
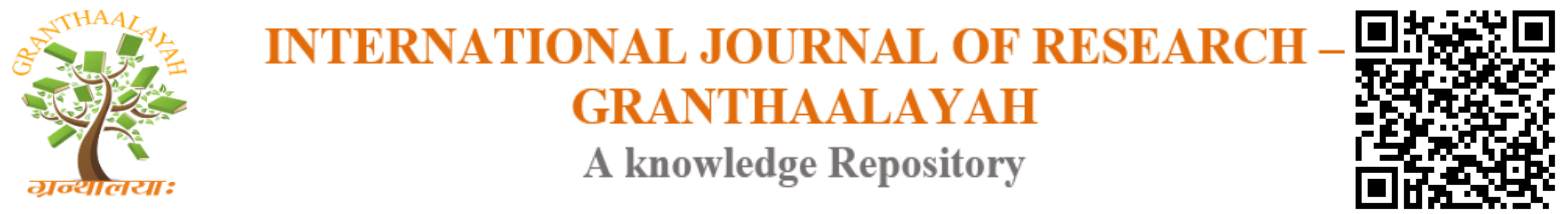

Management

\title{
BOARD SIZE AND CORPORATE PERFORMANCE OF QUOTED COMMERCIAL BANKS IN NIGERIA
}

\author{
Otuedon Ajuyitse Martins ${ }^{* 1}$, Ogbole Philip Osemudiamen ${ }^{2}$ \\ ${ }^{* 1,2}$ Accounting, Igbinedion University Okada, Nigeria
}

\begin{abstract}
The study examines board size and corporate performance of quoted companies in Nigeria. The objectives of the study are to examine the relationship between board size and total asset of quoted Nigerian banks; to examine the relationship between board size and total revenue of quoted Nigerian banks; to examine the relationship between board size and net profit of quoted Nigerian banks. The study adopted panel research design and census survey approach. The population of this research consists of 21 commercial banks in Nigeria. Data were collected from secondary sources that is audited financial statements. The findings of the study showed that there is a negative relationship between board size and total assets; there is a positive relationship between board size and gross revenue; there is a positive relationship between board size and Net profit. From the above findings, the study concluded that there is a relationship exist between board size and corporate performance of quoted Nigerian banks. The study further recommend that commercial banks and quoted firms must ensure that a proper board of directors is composed in other to institute standards and controls that will boost the net income of the firm; regulatory bodies should ensure that firms constitute a board with a standard size of seven members. The board also must have professionals who have requisite knowledge in the business; firm's board must ensure that the committees in the board are most effective in safeguarding the asset of the organization and should continuously make decisions that will boost the revenue and net profit of the firm.
\end{abstract}

Keywords: Board Size; Corporate Performance; Net Profit; Gross Revenue; Total Asset.

Cite This Article: Otuedon Ajuyitse Martins, and Ogbole Philip Osemudiamen. (2019). "BOARD SIZE AND CORPORATE PERFORMANCE OF QUOTED COMMERCIAL BANKS IN NIGERIA." International Journal of Research - Granthaalayah, 7(1), 328-341. https://doi.org/10.29121/granthaalayah.v7.i1.2019.1059.

\section{Introduction}

Issues relating to the regulation control and governance of business enterprises in Nigeria are largely contained within the provisions of company legislation i.e. The Companies and Allied Matters Act (CAMA) 1990. The role of board size and to large extent corporate governance is becoming more useful when managers have an incentive to deviate from shareholders interest. Also, the impact of board regulation on companies has influence its performance positively. 
Corporate governance relates to how a business is directed and controlled. According to the Central Bank of Nigeria (CBN), corporate governance is the process by which the business activities of an institution are directed and managed. However, Lemo (2010) emphasized that corporate governance consists of body of rules of the game by which companies are managed. Part of these rules requires that a company constitute boards of directors, appoint an external auditor and has an audit committee. The whole essence of corporate governance is to ensure that the business is run well and investors receive a fair return. A firm is said to have observed corporate governance rule if the firm is managed with diligence, transparency, responsibility and accountability aimed at maximizing shareholders' wealth. A firm's board regulate the general mechanisms the firm and lead the management to act in the best interest of the company owners (shareholders) (Akinsulire, 2006). Corporate performance according to Adegbemi, Donald and Ismail, (2012) is an important concept which relates to the ways and manners in which the resources (human, machine, finance) of an institution are effectively used to achieve the overall corporate objective of an organization. What keeps an organization in business is simply its ability of judiciously use its available resources and make sure that the providers of economic resources and its managers mutually benefit from the use of the resources. The size of firm's board also relate to the size of professional that looks into the day to day performance of the firm. This means that if a board is large more professionals will be in the board and it will in turn affect the net income of the firm. Corporate performance and board size have received increasing emphasis both in practice and in academic research. The result of these emphases are that some researchers such as Higgs (2003), Lehn, K., Sukesh, P. and Zhao, M. (2004) opined that board size has positive influence on the performance of a firm because of capital contribution by board members and their professional skill which influence positive decisions for the firm and as such net earnings increased. While some other researchers like Akpan and Rima (2012) have concluded that large agency increase agency cost which impact negatively on the net earnings. Given these different developments, this research is focus on examining the effect of board size on corporate performance of listed commercial banks in Nigeria. The study covers a period of 5 years from 2013-2017. In the light of the above, the following hypotheses guide the study:

Ho1: There is no significant relationship between total asset and board size of quoted Nigeria banks.

$\mathrm{Ho}_{2}$ : There is no significant relationship between total revenue and board size of quoted Nigeria banks.

Ho3: There is no significant relationship between net profit and board size of quoted Nigeria banks.

\section{Literature Review}

This section present the conceptual framework, empirical review and theoretical issues on the effect of board size on corporate performance. Corporate boards of directors play a central role in the corporate governance of modern companies, and hence understanding this relationship is very important to our understanding of corporate governance. Much of the public debate on board structure has centered on pressure for smaller board size. It is argued that although larger board size initially facilitates key board functions, there comes a point when larger boards suffer from coordination and communication problems and hence board effectiveness (and firm performance) declines (Lipton and Lorsch, 1992) as cited by Guest (2009). The high-profile corporate failure of companies such as Enron and WorldCom internationally, and Leisure Net, Regal Treasury Bank 
Limited and Saambou Limited in South Africa has attracted both academic and commercial interest (Rossouw, 2005). There is now general agreement that when companies are well governed superior performance is promoted. However, despite this general agreement, two areas of tension in the governance literature remain unclear, namely the relationship between board composition and firm performance and the relationship between board size and firm performance. Similarly, there is obvious disagreement between the literatures that argues that board size can be positively associated with firm performance. However, other literature on board size has contested this and has argued for smaller boards (Wu, 2003) because of advantages related to cohesiveness and higher productivity, as well as their ability to monitor the firm more effectively than larger groups. Smaller boards are less likely to participate in social loafing and have lower coordination costs, but makes them less effective in monitoring (Rashid, 2011).

\subsection{Board Composition and Corporate Performance}

Board composition and decision can be influenced by total asset of the firm which represent the size of the firm. Because large asset represent capacity to generate internal funds (Short and Keasey, 1999), having a greater variety of capabilities (Majumdar and Chhibber, 1999), and having problems of coordination board composition and size will be structured for proper management of the asset. Prior empirical studies have widely investigated the structure and efficiency of board size on the size of a company's revenue. Much of the research highlights the crucial role of Board of Directors, considering it as a mechanism enhancing corporate and economic performance. According to Jensen (1993), companies with undersized Boards tend to become less effective if the gross revenue is high. Clearly, a high number of decision-makers in any committee may reduce their effort and give rise to some degree of free-riding when the revenue and activities generated by a firm is low. Size of board is highly dependent on gross revenue because it takes money to run a board. Net profit represent the balance income after expenses have been subtracted. This means that since large board incur more expenses that smaller board, the size of a firm size must be dependent on the net profit i.e if the form can accommodate large firm expenses compared to small board expenses. Interestingly, Adams and Mehran (2008) fail to find a negative effect of profit on board composition of U.S. banks.

Ujunwa, Nwakoby, Ugban (2012) studied Corporate board diversity and firm's performance: Evidence from Nigeria. The population was 212 publicly quoted companies, sample was 122 the sources of data was annual financial statement from 1991-2008. The generalised least square was used while the dependent variable was firm performance and independent variable were board gender, board nationality and board ethnicity. They found no significant relationship between board diversity and firm's performance.

Edem Okon Akpan1, Noor Afza Amran (2014) research on Board characteristics and company performance: Evidence from Nigeria was carried out using multiple regression technique on 90 sampled firms from the main board of Nigerian Stock Exchange from 2010 to 2012. Their empirical evidence shows that board size and board education are positively and significantly related to company performance. They further recommend legislation mandating companies listed on Nigerian Stock Exchange to appoint at least 30 to $35 \%$ of women on the board of directors. 


\section{Theoretical Issues}

\subsection{Agency and Resource Dependency Theories}

Agency and resource dependency theories support board with large number of directors whereas stewardship theory supports smaller board size for effective management. Monitoring the functioning of boards, or the 'control' role is an important focus of corporate governance research (Hillman \& Dalziel, 2003). The primary theoretical framework that relates this monitoring function to firm performance is derived from agency theory, which predicts that conflicts of interest can arise from the separation of ownership and control in organisations. From this perspective, the primary function of boards is to monitor the actions of managers (agents) in order to protect the interests of shareholders (principals) (Andreasson, 2011). Should management pursue their own interests at the expense of the shareholders' interests 'agency' costs typically arise (Berle \& Means, 1932) as cited by (Nicholson \& Kiel, 2007). Monitoring by boards of directors may therefore reduce the agency costs inherent in the separation of ownership and control and, in this way, improve firm performance. Agency theory also predicts that the incentives available to directors and boards vary and are therefore an important precursor to effective monitoring and that firm performance will therefore improve if these are aligned with the interests of shareholders. Another important function of a board is the provision of resources. This perspective represents the dominant perspective in the literature relating to the resource dependence (Hillman \& Dalziel, 2003) and stakeholder traditions. Pfeffer and Salancik (1978) note that "when an organisation appoints an individual to a board, it expects the individual will come to support the organisation, will concern himself with its problems, will invariably present it to others, and will try to aid the organisation". Boards may therefore offer the following four primary benefits: advice and counsel, legitimacy, channels for communicating information between external organisations and the firm, and preferential access to commitments or support from important elements outside the firm. Resource dependence logic therefore suggests that a board's provision of resources is directly related to firm performance (Nicholson \& Kiel, 2007). Resources help reduce the dependency between the organisation and external contingencies diminish uncertainty for the firm lower transaction costs and ultimately aid in the survival of the firm.

\section{Methodology}

This study adopted Panel research design. Panel research design enable the researcher to review data in trend and in a longitudinal manner. The population of this research consists of 21 commercial banks in Nigeria. These banks are; Access Bank, Citibank, Diamond Bank, Ecobank, Fidelity Bank, First Bank, First City, Monument Bank, Guaranty Trust Bank, Heritage Bank, Keystone Bank, Providus Bank, Skye Bank, Stanbic IBTC Bank, Standard Chartered Bank, Sterling Bank, Suntrust Bank, Union Bank of Nigeria, United Bank for Africa, Unity Bank, Wema Bank, Zenith Bank. The study utilize census survey approach which entails the complete enumeration of the population as such there is no need for sample size. This research will employ the use of ordinary least square regression method in data analysis while data analyzed were collected using content analysis.

\section{Model Specification}

The study employed the following model to analysis data collected. 
Corporate performance $($ Independent Variables $)=\beta 0+\beta_{1} \mathrm{TA}+\beta_{2} \mathrm{TR}+\beta_{3} \mathrm{NP}$

Where:

$\beta_{1} \mathrm{TA}=$ Total Asset

$\beta_{2} \mathrm{TR}=$ Total Revenue

$\beta_{3} \mathrm{NP}=$ Net profit after tax

Board Size $($ Dependent $)=\beta_{1}$ ExeD $+\beta_{2}$ NonExeD $+\beta_{3}$ IndD

Where:

$\beta_{1}$ ExeD = Number of executive directors

$\beta_{2}$ NonExeD $=$ Number of Non-executive directors

$\beta_{3}$ IndD $=$ Number of Independent Directors

Measurement of Variables

\begin{tabular}{|c|c|c|}
\hline $\mathbf{S} / \mathbf{N}$ & Variable & Measurement \\
\hline 1 & $\begin{array}{l}\text { Total Assets - } \\
\text { Independent Variable }\end{array}$ & $\begin{array}{l}\text { Measured by the Total asset amount at the end of the } \\
\text { financial year }\end{array}$ \\
\hline 2 & $\begin{array}{l}\text { Gross Revenue - } \\
\text { Independent Variable }\end{array}$ & $\begin{array}{l}\text { Measured by the total interest income at the end of the } \\
\text { financial year }\end{array}$ \\
\hline 3 & $\begin{array}{l}\text { Net Profit - Independent } \\
\text { Variable }\end{array}$ & Measured by the net profit after tax at the financial year \\
\hline 4. & $\begin{array}{l}\text { Board Size - Dependent } \\
\text { Variable }\end{array}$ & $\begin{array}{l}\text { Board Size is measured by the total number of directors } \\
\text { (Executive, Non-Executive and Independent directors) }\end{array}$ \\
\hline
\end{tabular}

We examined the descriptive statistics, correlation analysis, analysis of the variance, panel unit root and the regression diagnostic results. Table 4.1 below presents the results for the descriptive statistics conducted on the variables. In conducting the descriptive statistics, the sample was decomposed on the basis of the dependent variable and thus creating sub-samples. For the aggregate statistics, the result show BSIZE has mean $=12.41$ which suggest that the average board for firms under review is 12 , it has $\mathrm{S} . \mathrm{D}=2.7$, indicating that the there is a cluster around the mean. BSIZE has kutosis value of -0.709 which is $<2$ suggest that the distribution is platykurtic, in other words it implies that the distribution is flat. TASSET has a mean $=29226$ and relatively large standard deviation 3985047 which implies that there is a great deviation from the mean. TASSET has kurtosis 4.9>3 implies that distribution is Leptokurtic. This suggest that the distribution is fat tailed.

GREVEN has a mean value $=227037$ and standard deviation $=129436$ suggest that there is a cluster around the mean. Its kurtosis value $=0,27<3$ suggest a platykurtic distribution, which implies that the distribution is flat. Finally, NPROFIT $\{$ Mean=795990, S. D=78867.73\} implies that there is a cluster around the mean. Kurtosis value $2.38<3$ implies a platykurtic distribution which connotes that the distribution is flat.

Table 4.1: Descriptive Statistics

\begin{tabular}{|l|l|l|l|l|l|l|}
\hline & Mean & Maximum & Minimum & Std. Dev. & Kutosis & obs \\
\hline BSIZE & 12.4141 & 17 & 8 & 2.273 & -0.709 & \\
\hline TASSET & 29226 & 16179102 & 46000 & 3985047 & 4.923 & \\
\hline GREVEN & 227037 & 587944 & 21000 & 129436.7 & 0.279 & \\
\hline NPROFIT & 795990 & 384912 & 2500 & 78867.73 & 2.38 & \\
\hline
\end{tabular}

Source: Researcher's computation (2018) 
From table 4.2 above, the correlation coefficients of the variables are examined. However of particular interest to the study is the correlation between Board size and all other explanatory variables. As observed, a negative correlation exists between Board size and total assets $(\mathrm{r}=--$ 0.0717). Board size has positive correlation with GREVEN $(\mathrm{r}=0.1577)$ and NPROFIT $(\mathrm{r}=0.0137)$. TASSET is positively correlated with GREVEN ( $\mathrm{r}=0.176)$ and NPROFIT $(\mathrm{r}=0.262)$. Finally, GREVEN exhibited a positive correction with NPROFIT $(\mathrm{r}=0.77)$. The analysis of the correlation coefficients between the independent variables are quite low and this suggests that the potential for multicollinearity is reduced in the model.

Table 4.2: Pearson Correlation Results

\begin{tabular}{|l|l|l|l|l|}
\hline & BSIZE & TASSET & GREVEN & NPROFIT \\
\hline BSIZE & 1 & & & \\
\hline TASSET & -0.0717 & 1 & & \\
\hline GREVEN & 0.1577 & 0.176 & 1 & \\
\hline NPROFIT & 0.0137 & 0.262 & 0.775 & 1 \\
\hline
\end{tabular}

Source: Researcher's compilation (2018).

The table 4.3 show the regression assumptions test results. The results of the Jacque-bera statistics assesses the normality of the distribution of scores. The variance inflation factor (VIF) shows how much of the variance of a coefficient estimate of a regressor has been inflated due to collinearity with the other regressors. Basically, VIFs above 10 are seen as a cause of concern as observed, none of the variables have VIF's values exceeding 10 and hence none gave serious indication of multicollinearity. The ARCH test for heteroskedasticity was performed on the residuals as a precaution. The results showed probabilities in excess of 0.05 which lead us to reject the presence of heteroskedasticity in the residuals. The Lagrange Multiplier (LM) test for higher order autocorrelation reveals that the hypotheses of zero autocorrelation in the residuals were not rejected. This was because the probabilities (Prob. F, Prob. Chi-Square) were greater than 0.05. The LM test did not, therefore, reveal serial correlation problems for the model. The performance of the Ramsey RESET test showed high probability values that were greater than 0.05 , meaning that there was no significant evidence of miss-specification.

A well-established practice in individual time series work is to determine whether the individual variables are non-stationary (exhibit unit roots) and if they are related to one another in a stable long-run (cointegrated) relationship. In recent years, a number of investigators, notably Levin, Lin and Chu (2002), Breitung (2000), Hadri (2005), have developed panel-based unit root tests that are similar to tests carried out on a single series. Panel Unit root testing investigates if the residuals from the individual cross sections do not contain a unit root which suggests that there exists an equilibrium (stable) relationship that keeps the relevant variables in the models in proportion to one another in the long run (Baltagi, 2001). As can be readily seen, the study performed the ADF Fisher unit root test proposed by Maddala and $\mathrm{Wu}$ (1999) to determine whether the residuals of each of the variables exhibited a unit root. In this test, the null hypothesis of a unit root for all variables is set against the alternative hypothesis of no unit root. The p-values suggest that the hypothesis of no unit root can be rejected at least at the 5 percent level. As can be readily seen in table 4.2 above, the study performed the ADF Fisher unit root test proposed by Maddala and Wu (1999) to determine whether the residuals of each of the variables exhibited a unit root. In addition we also performed the PP-Fisher Unit root test as an additional check to confirm the stationarity 
of the data. In these tests, the null hypothesis of a unit root for all variables is set against the alternative hypothesis of no unit root. The p-values suggest that the hypothesis of no unit root can be rejected at least at the 5 percent level. With the stationarity condition of the series determined, we proceeded to conduct the regression analysis as we may at least be confident of the likelihood of non-spurious regression results.

Table 4.3: Regression Assumptions Test

\begin{tabular}{|c|c|c|}
\hline \multicolumn{3}{|l|}{ Normality test } \\
\hline Variable & Jacque-bera statistics & Prob \\
\hline BSIZE & 186057.4 & 0.00 \\
\hline TASSET & 11609.69 & 0.00 \\
\hline GREVEN & 3875.988 & 0.00 \\
\hline NPROFIT & 26860.43 & 0.00 \\
\hline \multicolumn{3}{|c|}{ Multicollinearity test } \\
\hline Variable & Coefficient Variance & Centred VIF \\
\hline BSIZE & 186057.4 & 0.00 \\
\hline TASSET & 11609.69 & 0.00 \\
\hline GREVEN & 3875.988 & 0.00 \\
\hline NPROFIT & 26860.43 & 0.00 \\
\hline \multicolumn{3}{|c|}{ Heteroskedasticity Test: ARCH } \\
\hline F-statistic $=4.383$ & Prob. F $(1,851)$ & 0.554 \\
\hline \multicolumn{3}{|c|}{ Breusch-Godfrey Serial Correlation LM Test: } \\
\hline F-statistic $=4.383$ & Prob. F $(1,851)$ & 0.564 \\
\hline \multicolumn{3}{|l|}{ Ramsey model test } \\
\hline F-statistic $=4.383$ & Prob. F $(1,851)$ & 0.932 \\
\hline \multicolumn{3}{|c|}{ Panel Unit Root test at levels with intercept } \\
\hline Variable & ADF-Fisher chi-square & P-value \\
\hline BSIZE & 325.460 & 0.033 \\
\hline TASSET & 366.128 & 0.00 \\
\hline GREVEN & 330.377 & 0.025 \\
\hline NPROFIT & 338.224 & 0.00 \\
\hline Variable & Philip-Perron chi-square & P-value \\
\hline BSIZE & 321.135 & 0.00 \\
\hline TASSET & 394.945 & 0.00 \\
\hline GREVEN & 393.102 & 0.00 \\
\hline NPROFIT & 428.683 & 0.00 \\
\hline
\end{tabular}

Source: Researcher's Computation (2018)

\subsection{Regression Analysis}

The regression analysis is conducted to show the effects of the predictors on TV. The estimations are conducted across several specifications. Firstly, we examine the predictors by categories and then provide fixed and random effect results for the entire sample. Next, we decomposed the distribution by creating covariates on the basis of age, total asset proxy for firm size and 
Profitability. The purpose is to provide more robust estimations and to examine sensitivity of our results to these decompositions. The regression results and analysis are presented below;

Table 4.4: Regression Analysis

\begin{tabular}{|l|l|}
\hline Variable & \multicolumn{1}{|c|}{ Panel OLS } \\
\hline C & 11.776 \\
& $\{23.58\}$ \\
& $(-1.7 \mathrm{E}-41)$ \\
\hline TASSET & $-1.328 \mathrm{E}^{*}$ \\
& $\{2.207\}$ \\
& $(0.036)$ \\
\hline GREVEN & $3.28 \mathrm{E}-06^{*}$ \\
& $\{2.191\}$ \\
& $(0.023)$ \\
\hline NPROFIT & $-9.5 \mathrm{E}-07$ \\
& $\{0.203\}$ \\
& $(0.832)$ \\
\hline $\mathrm{R}^{2}$ & 0.610 \\
\hline ADJ R & 0.520 \\
\hline F-Stat & 2.845 \\
\hline P(f-stat) & 0.042 \\
\hline
\end{tabular}

Source: Researcher's compilation (2018)*sig @ 5\%,. ()p-value \{\} t-values

Table 4.4 above shows the regression result on the relationship between board size and profitability. using OLS estimation. The result reveals that there is a negative relationship between board size and total assets $\mathrm{t}=\{2.20\}$ and $(\mathrm{p}=0.036)$ at $5 \%$. Gross revenue has positive relationship with board size as depicted by $\mathrm{t}=\{2.91\}$ and $(\mathrm{p}=0.023)$ at $5 \%$.

Finally, The net profit is also positive but not statistically significant relationship with board size as depicted by $\mathrm{t}=\{0.203\}$ and $(\mathrm{p}=0.832)$ at $5 \%$.

The model parameters are as follows; coefficient of determination $\left(\mathrm{R}^{2}\right)=61.3 \%$, ADJ $\mathrm{R}^{2}=52 \%$. These values suggest that the model explains about $61 \%$ of systematic variations in board size. The F-stat=2.8, P(f-stat $)=0.042$. The F-values confirm that the hypothesis of a significant linear relationship between the variables (dependent and independent) cannot be rejected at $5 \%$ level.

\subsubsection{Discussion of Results}

The robust estimation results for estimation reveals that board size has a negative relationship with total assets. This is at variance with theoretical expectation and logical deduction that board size is a function of firm size. Consequently, we accept Ho that there is no significant relationship between board size and total assets.

The result further shows that gross revenue is positively related with board size. This is in line with theoretical expectation and logical deduction that is there a direct link between board size and 
profitability. Consequently, we reject Ho that there is no significant relationship between board size and gross revenue.

Finally, the result shows that net profit has no significant relationship with board size. This result is at variance with theoretical expectation and logical deduction that is there a direct link between board size profitability. Consequently, we accept Ho that there is no significant relationship between board size and net profit

\begin{tabular}{|c|c|c|c|}
\hline Bsize & TAsset & GReven & NProfit \\
\hline 15 & 1245487 & 311021 & 23104 \\
\hline 15 & 1124587 & 333022 & 32000 \\
\hline 15 & 1457832 & 302061 & 29101 \\
\hline 15 & 1215872 & 331000 & 27333 \\
\hline 14 & 1102001 & 342001 & 25114 \\
\hline 12 & 14879452 & 298741 & 102000 \\
\hline 12 & 15009412 & 324012 & 106000 \\
\hline 13 & 15829450 & 385467 & 121000 \\
\hline 12 & 13379410 & 335489 & 119000 \\
\hline 12 & 16179102 & 400247 & 114000 \\
\hline 11 & 11354000 & 105578 & 89541 \\
\hline 11 & 11954000 & 124587 & 110000 \\
\hline 12 & 12111000 & 133245 & 98245 \\
\hline 12 & 15000000 & 155900 & 110000 \\
\hline 12 & 15245800 & 145823 & 107201 \\
\hline 15 & 1012400 & 110000 & 12000 \\
\hline 15 & 1200000 & 109000 & 9000 \\
\hline 14 & 1100000 & 125000 & 39000 \\
\hline 14 & 1350000 & 133300 & 32000 \\
\hline 15 & 1210000 & 128000 & 29000 \\
\hline 10 & 2980000 & 587944 & 287412 \\
\hline 10 & 2874000 & 566812 & 310000 \\
\hline 10 & 2855400 & 551900 & 207000 \\
\hline 11 & 2990000 & 548000 & 287412 \\
\hline 11 & 2870018 & 548811 & 387412 \\
\hline 17 & 2984574 & 424057 & 212547 \\
\hline 14 & 2900000 & 399825 & 200522 \\
\hline 15 & 2970500 & 411000 & 210548 \\
\hline 15 & 2980000 & 399885 & 212500 \\
\hline 15 & 2984789 & 412012 & 211000 \\
\hline 9 & & 112046 & \\
\hline 8 & & 124587 & \\
\hline 8 & & 221457 & \\
\hline 8 & & 235478 & \\
\hline 9 & & 278412 & \\
\hline
\end{tabular}




\begin{tabular}{|l|l|l|l|}
11 & 2400000 & 250060 & 148000 \\
\hline 11 & 2550800 & 204000 & 103072 \\
\hline 10 & 2457123 & 200000 & 102779 \\
\hline 12 & 2458000 & 201247 & 102000 \\
\hline 14 & 2012400 & 210000 & 98502 \\
\hline 14 & 1900000 & 209000 & 63010 \\
\hline 14 & 1700000 & 225000 & 72420 \\
\hline 14 & 2012450 & 233300 & 88080 \\
\hline 14 & 2145360 & 228000 & 95509 \\
\hline 13 & 1012400 & 354087 & 12000 \\
\hline 13 & 120,000 & 355000 & 9000 \\
\hline 13 & 1100000 & 354000 & 39000 \\
\hline 14 & 1350000 & 351080 & 32000 \\
\hline 14 & 1210000 & 354000 & 29000 \\
\hline 9 & 1012400 & 220000 & 67000 \\
\hline 9 & 1200000 & 229000 & 51000 \\
\hline 9 & 1100000 & 225000 & 55000 \\
\hline 10 & 1350000 & 233300 & 31000 \\
\hline 10 & 1210000 & 228000 & 31000 \\
\hline 15 & 1012400 & 110000 & 12000 \\
\hline 15 & 1200000 & 109000 & 9000 \\
\hline 15 & 1100000 & 125000 & 39000 \\
\hline 15 & 1350000 & 133300 & 32000 \\
\hline 15 & 1210000 & 130000 & 29000 \\
\hline 12 & 1012400 & 250000 & 137000 \\
\hline 12 & 1200000 & 242001 & 121000 \\
\hline 12 & 1100000 & 220000 & 122000 \\
\hline 13 & 1350000 & 211000 & 131000 \\
\hline 13 & 1210000 & 237000 & 134000 \\
\hline 16 & 2015000 & 355782 & 201000 \\
\hline 16 & 2200000 & 355000 & 198000 \\
\hline 16 & 2100000 & 335000 & 144000 \\
\hline 15 & 2018000 & 311000 & 122010 \\
\hline 15 & 2011000 & 310782 & 128010 \\
\hline 10 & 2454812 & 251270 & 101000 \\
\hline 10 & 2500800 & 262000 & 98000 \\
\hline 12 & 2433000 & 214000 & 77000 \\
\hline 12 & 2000812 & 271270 & 78400 \\
\hline 12 & 2111812 & 200270 & 99010 \\
\hline 13 & 1500400 & 110000 & 6600 \\
\hline 13 & 1200000 & 109000 & 5040 \\
\hline & & & \\
\hline
\end{tabular}




\begin{tabular}{|c|c|c|c|}
\hline 13 & 1100000 & 125000 & 11000 \\
\hline 10 & 1300000 & 133300 & 11021 \\
\hline 11 & 1200000 & 128000 & 11024 \\
\hline 14 & 812400 & 98000 & 3000 \\
\hline 14 & 900000 & 72000 & 5000 \\
\hline 14 & 780,000 & 90000 & 7000 \\
\hline 14 & 895,000 & 50300 & 4000 \\
\hline 14 & 777,000 & 78000 & 6000 \\
\hline 11 & $1,012,400$ & 110000 & 12000 \\
\hline 11 & $1,200,000$ & 109000 & 9000 \\
\hline 13 & $1,100,000$ & 125000 & 39000 \\
\hline 13 & $1,350,000$ & 133300 & 32000 \\
\hline 12 & $1,210,000$ & 128000 & 29000 \\
\hline 8 & 54,000 & 22000 & 2500 \\
\hline 8 & 56,000 & 21000 & 3500 \\
\hline 8 & 53,000 & 25000 & 5500 \\
\hline 8 & 52,200 & 30300 & 5300 \\
\hline 8 & 46,000 & 28000 & 4200 \\
\hline 12 & $2,300,012$ & 189000 & 12000 \\
\hline 13 & $2,300,000$ & 156000 & 55000 \\
\hline 13 & $2,300,012$ & 125000 & 39000 \\
\hline 13 & $2,589,702$ & 147000 & 32000 \\
\hline 13 & $2,400,000$ & 181000 & 29000 \\
\hline
\end{tabular}

\begin{tabular}{|l|l|l|l|l|l|l|}
\hline \multicolumn{2}{|l|}{ SUMMARY OUTPUT } & & & & & \\
\hline Regression Statistics & & & & & \\
\hline Multiple R & 0.761305 & & & & & \\
\hline R Square & 0.610019 & & & & & \\
\hline Adjusted R Square & 0.520474 & & & & & \\
\hline Standard Error & 2.277704 & & & & & \\
\hline Observations & 99 & & & & & \\
\hline ANOVA & & & & & & \\
\hline & $d f$ & $S S$ & $M S$ & $F$ & Significance F & \\
\hline Regression & 3 & 13.16637 & 4.388788 & 2.845961 & 0.0422106 & \\
\hline Residual & 95 & 492.8538 & 5.187935 & & & \\
\hline Total & 98 & 506.0202 & & & & \\
\hline & Coefficients & Standard Error & t Stat & P-value & Lower 95\% & Upper 95\% \\
\hline Intercept & 11.7764 & 0.499271 & 23.5872 & $1.7 \mathrm{E}-41$ & 10.78522 & 12.76757 \\
\hline TAsset & $-1.3 \mathrm{E}-08$ & $6.12 \mathrm{E}-08$ & -2.20726 & 0.036247 & $-1.3 \mathrm{E}-07$ & $1.09 \mathrm{E}-07$ \\
\hline GReven & $3.28 \mathrm{E}-06$ & $2.75 \mathrm{E}-06$ & 2.19087 & 0.023667 & $-2.2 \mathrm{E}-06$ & $8.75 \mathrm{E}-06$ \\
\hline NProfit & $-9.5 \mathrm{E}-07$ & $4.65 \mathrm{E}-06$ & -0.20395 & 0.838828 & $-1 \mathrm{E}-05$ & $8.28 \mathrm{E}-06$ \\
\hline
\end{tabular}




\section{Correlation}

\begin{tabular}{|l|l|l|l|l|}
\hline & Bsize & TAsset & GReven & NProfit \\
\hline Bsize & 1 & & & \\
\hline TAsset & -0.0717 & 1 & & \\
\hline GReven & 0.157746 & 0.176116 & 1 & \\
\hline NProfit & 0.013781 & 0.262989 & 0.77528 & 1 \\
\hline
\end{tabular}

\begin{tabular}{|l|l|l|l|l|}
\hline & Bsize & TASSET & Greven & Nprofit \\
\hline Mean & 12.41414 & 2922640 & 227037.1 & 79590.2 \\
\hline Standard Error & 0.228377 & 411026.2 & 13008.87 & 8134.586 \\
\hline Median & 13 & 1350000 & 214000 & 53000 \\
\hline Mode & 15 & 1200000 & 125000 & 32000 \\
\hline Standard Deviation & 2.272327 & 3985047 & 129436.7 & 78867.73 \\
\hline Sample Variance & 5.163471 & $1.59 \mathrm{E}+13$ & $1.68 \mathrm{E}+10$ & $6.22 \mathrm{E}+09$ \\
\hline Kurtosis & -0.70964 & 4.92357 & 0.279947 & 2.383914 \\
\hline Skewness & -0.39474 & 2.506961 & 0.763671 & 1.481385 \\
\hline Range & 9 & 16133102 & 566944 & 384912 \\
\hline Minimum & 8 & 46000 & 21000 & 2500 \\
\hline Maximum & 17 & 16179102 & 587944 & 387412 \\
\hline Sum & 1229 & $2.75 \mathrm{E}+08$ & 22476669 & 7481479 \\
\hline Count & 99 & 94 & 99 & 94 \\
\hline Largest (1) & 17 & 16179102 & 587944 & 387412 \\
\hline Confidence Level (95.0\%) & 0.453208 & 816216.6 & 25815.69 & 16153.67 \\
\hline
\end{tabular}

\section{Conclusion and Recommendation}

Thus, our findings from the study indicates that:

- There is a negative relationship between board size and total assets

- There is a positive relationship between board size and gross revenue

- There is a positive relationship between board size and Net profit. Although this relationship was not statistically significant.

From the forgoing, the research clarifies the effect of the board size and its activities on the performance of commercial banks in Nigeria. Board size and its structure is very important to firm in areas of ensuring that all controls that will safe guard the assets of the organization are in place. A Board with competent and professional individual will in no little way contribute to the net income of any firm. Gross revenue and net profit have been proved to increase if the board is properly constituted with effective and professional individuals. The result of negative relationship between board size and total does not negate it importance it only refers to the size as to whether the small size board is more effective on total asset or large size board. A firm's board according to Companies and Allied Matters Act 2004 and Securities and Exchange Commission must have a minimum of seven members which includes the managing director. From the research general result has fully explain the high importance of company's board on Gross revenue, net profit and 
the total performance of firms. The study further recommended that; (1) Commercial banks and quoted firms must ensure that a proper board of directors is composed in other to institute standards and controls that boost the net income of the firm. (2) Regulatory bodies should ensure that firms constitute a board with the standard size. This board also must have professionals who have requisite knowledge in the business. (3) Firm's board must ensure that the committees in the board are most effective in safe guarding the asset of the organization. (4) Firm's board should continuous make decisions that will boost the revenue and net profit of the firm.

\section{References}

[1] Abdulazeez, D. A., Ndibe, L. \& Mercy, A.M. (2016). Corporate governance and financial performance of listed deposit money banks in Nigeria. $J$ Account Mark, 5, 153.

[2] Adams, R. \& Mehra, H. (2002). Board structure and banking firm performance. Working Paper, Federal Reserve Bank of New York.

[3] Adams, R.B. \& Mehran, H. (2005). Corporate performance, board structure and its determinants in the banking industry. EFA 2005 MOSCOW Meetings.

[4] Adegbemi, O., Donald, I.E. \& Ismail, O. (2012). Corporate governance and bank performance: A pooled study of selected banks in Nigeria. European Scientific Journal, 8, 155-164.

[5] Ajola, O., Amuda, T. \& Arulogum, L. (2012). Evaluating the effects of corporate governance on the performance of Nigerian banking sector. Review of Contemporary Business Research 1, 32-42.

[6] Akinsulire, O. (2006). Financial management, (4 ${ }^{\text {th }}$ ed.) Lagos: Gemosl Nigeria Ltd, Nigeria.

[7] Akpan, E. \& Roman, H.B. (2012). Does corporate governance affect bank profitability Evidence from Nigeria. American International Journal of Contemporary Research, 2, 135-145.

[8] CBN (2006). CBN Code of Corporate Governance for Banks in Nigeria Post Consolidation, Nigeria Abuja

[9] CBN (2014). Code of Corporate Governance for Banks and Discount Houses in Nigeria. Effective: Central Bank of Nigeria (CBN) Publication.

[10] Demaki, G.O. (2011). Proliferation of codes of corporate governance in Nigeria and economy development. Business Management Review, 1, 1-7.

[11] Edem, O.A. \& Noor, A.A. (2014). Board characteristics and company performance: Evidence from Nigeria. Journal of Finance and Accounting, 2(3), 81-89.

[12] Egunike, E. \& Aroh, (2015). The influence of corporate governance on earnings management practices: A study of some selected quoted companies in Nigeria. American Journal of Economics, Finance and Management, 1(5), 482-493.

[13] Financial dictionary (2018).

[14] Guest, P.M. (2008). The determinants of board size and composition: Evidence from the UK. Journal of Corporate Finance, 14, 51-72.

[15] Higgs, D. (2003). Review of the role and effectiveness of non-executive directors, Department of Trade and Industry/HMSO, London.

[16] Hillman, A. \& Dalziel, T. (2003). Boards of directors and firm performance: Integrating agency and resource dependency perspective. Academy of Management Review, 28(3), 383-396.

[17] Jensen, M.C. (1993). The modern industrial revolution, exit, and the failure of internal control systems. Journal of Finance, 48(3), $831-80$.

[18] Lehn, K., Sukesh, P. and Zhao, M. (2004). Determinants of the size and structure of corporate boards: 1935-2000, Working Paper, Katz Graduate School of Business.

[19] Lemo, T. (2010). Keynote address of the 34th conference of ICSAN. Lagos.

[20] Lipton, M. \& Lorsch, J.W. (1992). A modest proposal for improved corporate governance. Business Lawyer, 48(1), 59-77. 
[21] Lubabah, M. \& Bawa, A. (2013). Board composition, executive duality and performance of banks in the post consolidated era in Nigeria. International Journal of Academic Research in Economics and Management Sciences 2, 109-122.

[22] Nicholson, G.J. \& Kiel, G.C. (2007). Can directors impact performance? A case-based test of three theories of corporate governance. Corporate Governance: An International Review, 15, 585-608.

[23] Okike, E.N. (2007). Corporate governance in Nigeria the statuesque. Corporate Governance: An International Review, 15(2), 173-195.

[24] Pfeffer, J. (1972). Size, composition of corporate boards of directors: The organization and its environment. Administrative Science Quarterly, 218 - 228.

[25] Pfeffer, J. \& Salancik, G.R. (1978). The external control of organizations: A resource dependence perspective. Harper \& Row, New York.

[26] Randoy, T., Oxelheim, L. \& Thomsen, S. (2006). A Nordic perspective on corporate board diversity. Working Paper, Nordic Innovation Centre, Oslo, November.

[27] Ujunwa, A., Nwakoby, I. \& Ugbam, C.O. (2012). Corporate board diversity and firm performance: Evidence from Nigeria. Corporate Ownership \& Control, 9(2-1), 216226. http://dx.doi.org/10.22495/cocv9i2c1art6

[28] Ukenna, S.I. (2014). Sustainable consumption behaviour in Nigeria: Patterns, inhibitors and facilitators. Unpublished PHD Dissertation, Department of Marketing, Nnamdi Azikiwe University.

[29] Wikipedia (2018).

[30] Wu, Y. (2003). The impact of public opinion on board structure changes, director career progression, and CEO turnover: Evidence from CALPERS' corporate governance program. Journal of Corporate Finance, 10, 199-227.

*Corresponding author.

E-mail address: philip4accounting@yahoo.com/otuedonmartins@ yahoo.com 